\title{
Peningkatan Hasil Beljaar Bahasa Indonesia melalui Metode Inquiri Pada Siswa Kelas VI SDN 1 Tamanan
}

\author{
Suci Rahayu
}

SDN 1 Tamanan Kecamatan Trenggalek

rahayusuci95@yahoo.com

\section{Tersedia Online di \\ http://www.jurnal.unublitar.ac.id/ index.php/briliant}

\begin{tabular}{l}
\hline Sejarah Artikel \\
\hline Diterima pada 2 April 2017 \\
Disetuji pada 11 April 2017 \\
Dipublikasikan pada 1 Mei 2017 \\
Hal. 239-246 \\
\hline
\end{tabular}

Kata Kunci:

hasil belajar; inquiri, surat resmi,

\begin{abstract}
ABSTRAK: Tujuan penelitian ini adalah untuk memperoleh gambaran objektif tentang peningkatan hasil belajar Bahasa Indonesia materi surat resmi dengan metode inquiry pada siswa. Penelitian menggunakan metode penelitian tindakan kelas. Subjek dalam penelitian ini adalah siswa Kelas VI SDN 1 Tamanan Trenggalek Pelajaran 2013/2014. Hasil Penelitian menunjukkan Peningkatan dari hasil pretes nilai rata-rata prestasi 57,46. Evaluasi siklus I diperoleh nilai rata-rata $69,74(47,37 \%)$ mencapai ketuntasan. Pada siklus II nilai rata-rata yang diperoleh 82,89 $(89,47 \%)$ mencapai ketuntasan meningkat $42,11 \%$ dari siklus sebelumnya.
\end{abstract}

Menulis surat resmi merupakan salah satu bagian dalam pembelajaran mata pelajaran Bahasa Indonesia yang dianggap sulit dan membosankan karena ada kendala-kendala yang dihadapi seperti kemampuan guru, kemampuan siswa, metode pembelajaran, situasi dan kondisi pembelajaran, serta beberapa variable penghambat lain. Pembelajaran menulis surat resmi dengan metode inquiry merupakan alternatif untuk dapat memudahkan dan menunjang siswa dalam peningkatan hasil belajar penulisan surat resmi. Setelah memahami benar kegiatan penulisan surat resmi dengan metode inquiry tersebut, siswa akan dapat menerapkan sendiri sesuai dengan kemampuannya masing-masing.

Hasil diskusi dengan observer dan kepala sekolah menunjukkan bahwa pembelajaran penulisan surat resmi dengan metode inquiry membuat siswa mempunyai gambaran dan minat yang tinggi dalam mempelajari surat resmi dan fungsinya. Pembelajaran menulis surat resmi dengan metode inquiry merupakan alternatif untuk dapat memudahkan dan menunjang siswa dalam peningkatan hasil belajar menulis surat resmi. Guru sebagai fasilitator dan pembimbing dalam kegiatan belajar mengajar sangat dibutuhkan oleh siswa. Dengan memahami benar kegiatan penulisan surat resmi dengan metode inquiry tersebut, siswa akan dapat menerapkan sendiri sesuai dengan kemampuannya masing-masing, akan merasa senang dan mudah serta dapat menikmati pengarahan-pengarahan dalam bentuk pertanyaan, siswa tingkat SD akan dapat mengungkapkan gagasan/ide menjadi surat resmi dengan sistematika yang tepat dan bahasa baku.

Hasil belajar merupakan serangkaian data, kecakapan, keterampilan, kematangan, pemahaman, dan kemampuan yang dimiliki oleh seseorang setelah melalui suatu proses belajar. Hasil belajar merupakan kemampuan yang diperoleh individu setelah proses belajar berlangsung, yang dapat memberikan 
perubahan tingkah laku baik pengetahuan, pemahaman, sikap dan keterampilan mahasiswa sehingga menjadi lebih baik dari sebelumnya. Sebagaimana yang dikemukakan Hamalik (2011:111) hasil belajar adalah perubahan tingkah laku subjek yang meliputi kemampuan kognitif, afektif dan psikomotor dalam situasi tertentu berkat pengalamannya berulang-ulang. Pendapat tersebut didukung oleh Sudjana (2011:24) hasil belajar ialah perubahan tingkah laku yang mencakup bidang kognitif, afektif, dan psikomotor yang dimiliki siswa setelah menerima pengalaman belajarnya. Suryono, Haryanto (2011:28) menyatakan bahwa belajar adalah proses perubahan melalui kegiatan atau prosedur latihan, baik latihan di dalam laboratorium maupun dalam lingkungan rumah. Belajar menurut konsepsi modern adalah suatu proses perubahan tingkah laku dalam arti seluas-luasnya meliputi pengamatan, pengenalan, pengertian pengetahuan, perbuatan, keterampilan perasaan, minat, penghargaan dan sikap.

Perubahan hasil belajar menyangkut tiga aspek yaitu kognitif, afektif dan psikomotor. Hasil belajar juga merupakan konsep yang bersifat umum, di dalamnya terdapat apa yang dinamakan prestasi belajar. Sedangkan prestasi belajar adalah tingkat keberhasilan siswa dalam mempelajari materi pelajaran di sekolah yang dinyatakan dalam bentuk skor yang diperoleh dari hasil tes mengenai sejumlah materi pelajaran. Oleh karena itu, untuk mengetahui sejumlah mana perubahan yang dialami oleh siswa dilakukan kegiatan penilaian, yaitu tindakan atau kegiatan untuk melihat sejauh mana tujuan pembelajaran dapat dicapai oleh siswa dalam bentuk hasil belajar yang diperoleh setelah mereka menempuh prosesbelajar. Jadi hasil belajar pada hakikatnya adalah perubahan tingkah laku yang tejadi pada siswa setelah menempuh pengalaman belajar (Nana Sujana, 2011).

Surat resmi adalah semua surat yang berisikan masalah keresmian atau administrasi keresmian atau pemerintahan. Surat diterbitkan oleh kantorkantor jawatan pemerintahan disebut surat resmi. Perbedaan antara surat dinas dan surat resmi adalah tujuan dan sifat penulisan. Secara umum surat berfungsi sebagaimana tercermin dalam rumusan pengertiannya yaitu sebagai alat komunukasi tertulis untuk menyampaikanpesan atau informasi. Akan tetapi secara khusus fungsi surat resmi sebagai duta atau wakil penulis, sebagai pedoman kerja, seperti surat keputusan atau surat instruksi, dan sebagai bukti tentang yang dikomunikasikan dan administratif.

Syarat dasar penulis surat resmi memiliki kemampuan penguasaan materi, penguasaan bahasa resmi atau bahasa formal, penguasaan pikiran dan perasaan si penerima, pengetahuan mengenai posisi dalam hubungan kerja antara penulis dan pembaca, dan pengetahuan korespodensi. Langkah teknis menulis surat resmi menurut Renaldi (a) penegasan tujuan pokok penulisan surat resmi, (b) pengumpulan data, (c) Perkiraan tentang pembaca, (d) penyusunan draf atau konsep, dan (e) penyelesaian.

Salah satu hal menentukan baik dan kurang baiknya suatu surat adalah format atau tata letak posisi bagian-bagian surat resmi. Bagian surat resmi yaitu bagian kepala, bagian tubuh, dan kakisurat. Masing-masing bagian terdiri dari sub bagian-sub bagian (a) kepala surat, (b) tanggal surat, (c) nomor surat, (d) lampiran, (e) hal atau perihal, (d) alamat surat, (e) salam pembuka, (f) isi surat, (g) salam penutup, (h) tanda tangan penulis atau penanggung Jawab dan nama terang.

240 BRILIANT: Jurnal Riset dan Konseptual Volume 2 Nomor 2, Mei 2017 
Bahasa dalam surat resmi hendaknya menggunakan bahasa yang benar, sesuai dengan kaidah ejaan yang disempurnakan, penyusunan kalimat dan penyusunan paragraf. Kalimat berupa kalimat efektif, yaitu kalimat yang sesuai dengan kaidah bahasa, singkat, dan enak dibaca, tidak bertele-tele, tidak berbilit-bilit, sopan dan simpatik, tidak bernada menghina atau meremehkan pembaca. Setiap gagasan disusun dalam satu paragraph yang utuh, yakni paragraf yang memenuhi syarat adanya kesatuan dan kepaduan.

Jenis surat berdasarkan isinya adalah (1) surat pribadi, (2) surat resmi, (3) surat niaga. Sedangkan surat berdasarkan keamanan isinya terbagi menjadi (1) surat sangat rahasia, (2) surat rahasia, (3) surat konfidensial, (4) surat biasa. Jenis surat berdasarkan jumlah pembaca yang dikenhendaki menjadi (1) surat edaran, (2) surat biasa, (3) surat pengumuman. Bentuk surat adalah tata letak atau posisi bagian-bagian surat. Masing-masing bagian amat penting peranannya untuk menjadi bahan identifikasi atau petunjuk memproses surat itu. Pemakaian bentuk surat oleh setiap organisasai atau instansi berbeda tergantung kepada kebiasaan atau peraturan instansi itu. Bentuk-bentuk surat antara lain bentuk lurus penuh (full block style), bentuk lurus (block style), bentuk tekuk (indented style), bentuk setengah lurus dua variasi (bentuk resmi Indonesia lama dan bentuk resmi Indonesia baru).

Metode inquiry dan discovery pada dasarnya dua metode pembelajaran yang saling berkaitan satu dengan yang lain. Inquiry artinya penyelidikan, sedangkan discovery adalah penemuan. Sebagaimana ungkapan diatas langkah-langkah pemecahan masalahmerupakan suatu pendekatan yang dipandang cukup ilmiah dalam melakukanpenyelidikan dalam rangka memperoleh suatu penemuan. Semua langkah yang ditempuh dari mulai merumuskan masalah, hipotesis, mengumpulkan data, menguji hipotesis dengan data dan menarik kesimpulan jelas membimbing siswauntuk selalu menggunakan pendekatan ilmiah dan berpikir secara objektif dalam memecahkan masalah. Jadi dengan penerapan metode ini, siswa melakukan suatu proses mental yang bernilai tinggi,d isamping proses kegiatan fisik lainnya.T iga macam cara pelaksanaan metode inquiry dan discovery. Sumiati, dkk. berpendapat bahwa inquiry atau menemukan, yaitu melaksanakan sejauh mungkin kegiatan inquiry untuk semua topik. Siswa diberi pembelajaran untuk penanganan permasalahan yang mereka hadapi ketika mereka berhadapan dengan dunia nyata. Guru merencanakan situasi sedemikian rupa, sehingga para siswa bekerja menggunakan prosedur mengenali masalah, menjawab pertanyaan, menggunakan prosedur penelitian/investigasi, dan menyiapkan kerangka berpikir, hipotesis dan penjelasan yang relevan dengan pengalaman pada dunia nyata.

Langkah-langkah umum dalam melaksanakan metode ini secara umum identifikasi kebutuhan siswa, seleksi pendahuluan terhadap prinsipprinsip pengertian, konsep, dan generalisasi yang akan dipelajari, seleksi materi pembelajaran dan problema atau tugas-tugas, membantu memperjelas tugas problema yang akan dihadapi dan peranan masing-masing siswa, mempersiapkan setting kelas dan alat-alat yang diperlukan, mencek pemahaman siswa terhadap masalah yang akan dipecahkan dan tugas-tugas siswa, member kesempatan kepada siswa untuk melakukan penemuan, membantu siswa dengan informasi/data jika diperlukan, memimpin analisis

241 BRILIANT: Jurnal Riset dan Konseptual Volume 2 Nomor 2, Mei 2017 
sendiri dengan pertanyaan yang mengarahkan dan mengidentifikasi proses, merangsang terjadinya interaksi antarsiswa, memuji dan membesarkan siswa yang tergiat dalam proses penemuan, membantu siswa merumuskan prinsipprinsipdan generalisasi atas hasil penemuan. Tujuan penerapan pembelajaran dengan metode inquiry dapat meningkatkan hasil belajar Bahasa Indonesia materi menulis surat resmi pada siswa kelas VI SDN 1 Tamanan KecamatanTrenggalek.

\section{METODE}

Metode yang digunakan dalam penelitian ini adalah Penelitian Tindakan Kelas (PTK)."Penelitian Tindakan Kelas merupakan suatu penelitian tindakan dalam bidang pendidikan yang bertujuan untuk memperbaiki atau meningkatkan mutu pembelajaran di kelas". Penelitian Tindakan Kelas yaitu suatu bentuk penelitian yang bersifat reflektif dengan melakukan tindakan-tindakan tertentu agar dapat memperbaiki atau meningkatkan praktek-praktek pembelajaran di kelas secara lebih propesional. Perbaikan pembelajaran dilaksanakan melalui proses pengkajian berdaur, yang terdiri dari empat tahap yaitu perencanaan (planning), pelaksanaan (action), mengamati (observation), dan refleksi (reflection). Subjek dalam penelitian ini adalah siswa kelas VI SDN 1 Tamanan Kecamatan Trenggalek, yang terdiri dari 19 siswa, yang terdiri dari 11 orang siswa laki-laki dan 8 orang siswa perempuan.

\section{Rancangan Penelitian Observasi Awal}

Kegiatan penelitian ini dimulai dengan observasi awal dengan pemberian uji kompetensi sebagai langkah dasar untuk mengidentifikasi permasalahan dalam upaya menindaklanjuti pada proses identifikasi perlakuan standardisasi penelitian sebelum dan sesudah dilakukan program pembelajaran terkendali dengan berbagai model pembelajaran. Tujuan untuk meningkatkan kemampuan kreatif siswa.

\section{Perencanaan Tindakan}

Setelah mengkaji hasil identifikasi observasi awal tindakan, dilakukakan identifikasi masalah, kajian teori relevan, merumuskan fokus kajian penelitian, selanjutnya dilakukan perencanaan tindakan dengan merancang rencana pelaksanaan pembelajaran, mengadakan lembar kerja siswa, instrumen tes hasil belajar siswa, rubrik penilaian berpikir kreatif, lembar observasi guru dan siswa, serta format wawancara yang relevan dan fokus. Penelitian dirancang berdasarkan Model Kemmis \&Mc. Taggart. Tahapan penelitian tindakan kelas yang dikembangkan, yaitu: perencanaan (planning), tindakan (action), pengamatan (observation), dan refleksi (reflection).

\section{Planning (perencanaan)}

Rencana tindakan mencakup semua langkah tindakan sebagai berikut: 1) apa yang diperlukan untuk menentukan kemungkinan terpecahkannya masalah yang telah dirumuskan, 2) alat-alat dan teknik yang diperlukan untuk mengumpulkan data/ informasi, 3) rencana perekaman/pencatatan data dan 
pengolahannya, dan 4) rencana untuk melaksanakan tindakannya dan mengevaluasi hasilnya. Dalam hal ini perlu dilakukan pemilihan prosedur penelitian, dan prosedur pemantauan atau evaluasi. Semua keperluan dalam pelaksanaan penelitian, mulai dari materi, rencana pembelajaran, instrumen observasi dan lain-lain harus dipersiapkan dengan matang pada tahap ini. Pada tahapan ini perlu diperhitungkan bahwa kemungkinan tindakan sosial akan mengandung resiko, sehingga rencana ini harus fleksibel sehingga nantinya memungkinkan untuk diadaptasikan.

\section{Acting (tindakan)}

Tindakan yang dimaksud adalah implementasi dari semua rencana yang telah dibuat, dan biasanya berlangsung didalam kelas. Langkah-langkah yang dilakukan oleh guru tentu aja sesai dengan skenario yang telah disusun dalam rencana pembelajaran.

\section{Observing (pengamatan)}

Observasi dilakukan terhadap proses tindakan, pengaruh tindakan, keadaan dan kendala tindakan, dan persoalan lain yang terkait. Observasi mengumpulkan data-data dengan menggunakan instrumen atau alat lainnya yang telah dibuat secara valid. Pelaksanaan observasi tidak harus dilakukan oleh guru sendiri, tetapi melibatkan kolaborator (guru lain). Hanya saja pengamat/kolaborator tersebut jangan sampai melakukan intervensi pada proses pembelajaran yang sedang dilaksanakan. Metode pengumpulan data yang digunakan tidak menuntut waktu yang berlebihan dari guru sehingga tidak berpeluang mengganggu proses pembelajaran. Dengan kata lain sejauh mungkin harus menggunakan prosedur pengumpulan data yang dapat ditangani sendiri oleh guru sementara ia tetap aktif berfungsi sebagai guru yang bertugas secara penuh.

\section{Refelecting (refleksi)}

Tahapan ini merupakan kegiatan mengevaluasi dan meninjau kembali pelaksanaan pembelajaran dan hasil observasi yang dilakukan sebagai bahan pertimbangan untuk perbaikan atau perumusan tindakan lanjut. Langkah yang dilakukan (1) identifikasi permasalahan yang muncul, (2) analisis tindakan pembelajaran berdasarkan kendala, (3) tentukan langkah tindakan selanjutnya. Refleksi adalah mengingat atau merenung kembali pada tindakan yang telah dilakukan, dan dicatat dalam observasi. Dalam hal ini perlu untuk dipahami proses, permasalahan, dan kendala yang nyata dari tindakan yang telah dilakukan.

Proses refleksi ini data dari semua catatan kolaborator dianalisis, untuk menentukan apakah hipotesis tindakan telah tercapai, atau untuk menentukan perencanaan kembali siklus berikutnya. Subjek dalam penelitian ini adalah siswa kelas VI SDN 1 Tamanan Kecamatan Trenggalek, yang terdiri dari 19 siswa, yang terdiri dari 11 orang siswa laki-laki dan 8 orang siswa perempuan. Dalam penelitian ini, instrumen penelitian yang digunakan adalah tes hasil belajar. Ada tiga macam nilai yang diambil dari subjek penelitian yaitu kondisi awal, pretes dan nilai akhir siklus. Dari data-data tersebut akan dipergunakan untuk menentukan terjadinya peningkatan hasil belajar adalah nilai kondisi awal dan nilai akhir siklus. Teknik atau metode penelitian adalah langkah-langkah yang di 
tempuh dalam riset yang diatur secara baik, adapun metode yang dipakai adalah teknik tes. Teknik tes digunakan untuk memperoleh informasi-informasi tentang peningkatan-peningkatan keterampilan menulis surat resmi selama berlangsungnya proses pembelajaran menulis surat resmi dengan metode inquiry. Untuk mengetahui peningkatan hasil belajar siswa digunakan tes.

Pemberian tes dimaksudkan untuk mengukur seberapa jauh hasil yang diperoleh siswa setelah kegiatan pemberian tindakan. Tes menulis surat resmi diberikan pada awal kegiatan penelitian untuk mengidentifikasi kekurangan atau kelemahan siswa dalam menulis surat resmi dan setiap akhir siklus untuk mengetahui peningkatan mutu hasil menulis surat resmi siswa. Teknik analisis data yang digunakan dalam penelitian ini adalah deskriptif kualitatif. Dalam penelitian ini, data yang akan dianaliasis meliputi hasil lembar observasi keaktifan siswa, dan hasil belajar siswa.

Hasil belajar siswa dianalisis secara kuantitaif, sedangkan skala nilai yang digunakan adalah rentang nilai 10 sampai dengan 100. Menurut Arikunto (2011:45) analisis data dimaksudkan untuk mengetahui ketuntasan belajar siswa dalam kegiatan belajar mengajar. Perolehan nilai setiap siswa melalui tes hasil belajar menggunakan kriteria ketuntasan belajar klasikal dan nilai rata-rata. Kriteria untuk mengukur tingkat keberhasilan upaya perbaikan pembelajaran (1) proses perbaikan pembelajaran dinyatakan berhasil apabila siswa dapat menguasai minimal 70\% dari materi pembelajaran atau mendapat nilai 69, (2) proses perbaikan pembelajaran dinyatakan berhasil apabila $85 \%$ dari jumlah siswa tuntas belajar, (3) proses perbaikan pembelajaran dinyatakan berhasil apabila $85 \%$ dari jumlah siswa mengalami peningkatan keaktifan selama proses pembelajaran berlangsung.

\section{HASIL}

Hasil Penelitian kondisi awal menunjukkan bahwa pembelajaran yang dikembangkan guru masih menggunakan metode ceramah. Pembelajaran lebih sering didominasi oleh guru sedangkan siswa hanya menyimak dan mencatat, sehingga kemampuan pemahaman konsep siswa terhadap mata pelajaran Bahasa Indonesia kurang berkembang. Pada saat menyampaikan materi, guru langsung menjelaskan materi dari buku paket. Selain itu aktivitas siswa tidak optimal, hal ini terlihat dari anak kurang perhatian terhadap pembelajaran, kurangnya rasa antusias siswa untuk belajar, tidak teraktivitas, dan kurang aktifnya siswa dalam pembelajaran. Dalam proses pembelajaran, siswa hanya mendengarkan, mencatat penjelasan guru dan menjawab latihan soal yang ada dalam buku paket. Siswa tidak diberikan kesempatan untuk ikut aktif dalam percobaan, akibatnya pemahaman konsep siswa menjadi rendah dan hasil belajar siswa menurun.

\section{PEMBAHASAN}

Hasil siklus I setelah dilaksanakan perbaikan pembelajaran dengan memberikan pemahaman kepada siswa terhadap materi yang akan diterima serta problema serta tugas-tugas yang akan dihadapi pada pembelajaran menulis surat resmi. Rekapitulasi nilai tes pembelajaran Bahasa Indonesia materi, 9 siswa atau 47,37\% dinyatakan tuntas, 10 siswa atau 52,63\% dinyatakan belum tuntas belajarnya. Melihat hasil di atas maka peneliti bersama-sama dengan observer 
sepakat untuk melanjutkan pelaksanaan perbaikan pembelajaran pada siklus II karena perolehan nilai rata-rata hasil belajar secara klasikal baru mencapai 69,74 dan ketuntasan belajar secara klasikal baru mencapai angka 47,37\%, dengan harapan pada siklus II rata-rata hasil belajar siswa dapat mencapai perolehan di atas KKM sebesar 70,00 sesuai dengan kriteria keberhasilan yang telah ditetapkan dan tingkat ketuntasan belajar mencapai angka di atas $85 \%$ dari jumlah seluruh siswa.

Hasil pada siklus II setelah mempertimbangkan hasil refleksi pada siklus pertama, maka Pada siklus II didapat nilai rata-rata hasil belajar 82,89 jumlah siswa yang telah mencapai tingkat ketuntasan belajar 17 siswa $(89,47 \%)$, dan pada siklus kedua masih terdapat dua siswa $(10,53 \%)$ yang tidak tuntas, sehingga dapat disimpulkan bahwa semua siswa dinyatakan tuntas belajarnya pada siklus kedua. Melihat hasil di atas maka peneliti bersama-sama dengan observer menyimpulkan bahwa hasil tes hasil belajar menunjukkan hasil 89,47. Hal ini menunjukkan bahwa tes hasil belajar sudah memenuhi kriteria keberhasilan karena hasil belajar berada di atas angka kriteria minimal ketuntasan (KKM) sebesar 70, dengan jumlah siswa yang telah tuntas belajarnya sebanyak 17 siswa atau 89,47\% dan kepada siswa yang belum tuntas akan diadakan kegiatan remidial dengan ketentuan waktu yang akan ditetapkan menyusul.

Simpulan dari penelitian kondisi awal nilai rata-rata sebesar 57,46 dengan siswa tuntas sebanyak 2 siswa atau 10,53\%, siklus pertama nilai rata-rata sebesar 69,74 dengan siswa tuntas sebanyak 9 siswa atau 47,37\%, dan siklus kedua nilai rata-rata sebesar 82,89 dengan siswa tuntas sebanyak 17 siswa atau $89,47 \%$.

\section{KESIMPULAN}

Simpulan dari hasil penelitian didapat bahwa penerapan metode pembelajaran inquiry dalam upaya untuk meningkatkan hasil belajar Bahasa Indonesia materi surat resmi pada siswa kelas VI SDN 1 Tamanan Kecamatan Trenggalek semester II tahun pelajaran 2013/2014 dilakukan dua siklus yang masing-masing siklus dilakukan 1 kali pertemuan, masing-masing siklus terdiri dari empat tahap yaitu: perencanaan, pelaksanaan, observasi, dan refleksi. Pembelajaran dengan metode dilakukan dengan pemberian tugas menulis surat resmi pada pra siklus, siklusI, dan siklus II. Kondisi awal nilai rata-rata sebesar 57,46 dengan siswa tuntas sebanyak 2 siswa atau 10,53\%, siklus pertama nilai rata-rata sebesar 69,74 dengan siswa tuntas sebanyak 9 siswa atau 47,37\%, dan siklus kedua nilai rata-rata sebesar 82,89 dengan siswa tuntas sebanyak 17 siswa atau 89,47\% dinyatakan mampu meningkatkan pembelajaran Bahasa Indonesia focus pada pembelajaran menusli surat resmi pada anak didik kelas VI SDN Tamanan Trenggalek pada semester II.

\section{SARAN}

Disarankan kepada guru atau pendidik dapat menerapkan metode pembelajaran yang menyenangkan dan bervareasi, terutama metode inquiry dan juga metode kooperatif lainya untuk meningkatkan keterampilan menulis surat resmi dalam kegiatan belajar. Kepada peneliti selanjunya, hasil penelitian ini dapat digunakan sebagai inspirasi untuk mengadakan penelitian sejenis. Penelitian dapat dilakukan pada topik yang sama pada sekolah lain, 
atau juga pelejaran lain. Oleh karena itu peneliti harus melakukan observasi terlebih dahulu untuk mengadakan penelitian tindakan kelas, mencari penyebab kegagalan sesuatu pembelajaran baik dari pengamatan maupun wawancara dengan guru lain. Selain itu penelitian juga dapat dilakukan secara kolaboratif dengan guru lain.

\section{DAFTAR RUJUKAN}

Hamalik, Oemar. 2011. Kurikulum dan Pembelajaran. Jakarta: Bumi Aksara

Hartanto. 2009. Peningkatan Kemampuan Menulis Surat Pribadi Melalui Metode Pembelajaran Kontekstual (CTL) Siswa Kelas III SD Negeri Purbayan OI Baki Sukoharjo".

Suparmin. 2010. Klitika. Sukoharjo: Uinvet Bantara.

Sudjana, Nana. 2011. Penilaian Hasil Proses Belajar. Bandung: PT Remaja Rosdakarya.

Suryono, Haryanto. 2011. Belajar dan Pembelajaran. Bandung: PT. Rosdakarya 